WIELKIE TEMATY KULTURY W LITERATURACH SŁOWIAŃSKICH

Slavica Wratislaviensia CLXVIII • Wrocław 2019•AUWr No 3875

DOI: 10.19195/0137-1150.168.10

Data przesłania artykułu: 18.09.2017

Data akceptacji artykułu: 7.11.2017

ANNA HORNIATKO-SZUMIŁOWICZ

Uniwersytet im. Adama Mickiewicza w Poznaniu, Polska

\title{
На терезах долі. Мотиви й образи смерті в новелістиці Василя Ткачука
}

Попри факт, що мала проза маловідомого широкому загалу галицького новеліста 30-х років XX ст. Василя Ткачука (1916-1944) ${ }^{1}$ вважається опти-

${ }^{1}$ Василь Ткачук народився у 1916 році в селі Іллінці на Покуті в селянській сім’ї. Його, брата Олексія і сестру Марію виховувала мати. Батько помер у 1921 році. Василь виявився обдарованою дитиною, його перші літературні спроби випали на шкільні роки. Дебютну новелу Великдень іде Ткачук опублікував у 1933 році в журналі „Жіноча доля”. У 1934 році письменник переїхав у Львів, де став членом літературного угрупування „Дванадцятка”. У 1937 році одружився з Марією Януш. Через рік народилася єдина донька новеліста Ольга, яка досі живе в Щецині. Дедалі популярнішого Василя Ткачука захопило міське життя, він покинув сім'ю. Водночас почав з великим успіхом публікувати збірки новел. За життя письменника вийшли чотири його книжки: Сині чічки (1935), Золоті дзвінки (1936), Зимова мелодія (1938), Весна (1940). У 1941 році його покликали до лав Радянської армії. Загинув імовірно у 1944 році. Незважаючи на велику популярність Ткачука у 30-ті роки, що підтверджене схвальними відгуками тодішньої критики, радянська історіографія навмисне забула про творчість галицького новеліста. Він сам попав під цензуру і лише у 1973 році опублікувалась його невелика збірка Новели (1973). У наш час старанням дочки письменника Ольги Гоффманн вийшли дві збірки новеліста - Сині чічки (2013) і Золоті дзвінки (2014). Див., напр.: М. Рудницький, Сільський хлопчина дивиться на світ, „Діло” 1935, 19 листопада; М. Рудницький, Василь Ткачук „Весна”, „Література і мистецтво” 1940, № 1, с. 14-22; М. Семчишин, Село в нарисах Василя Ткачука, „Наш прапор” 1935, 17 жовтня; М. Голубець, Дебют новеліста, „Новий час” 1935, 10 листопада; О. Грицай, Цікавий дебют, „Свобода” 1936, № 109; Л. Нигрицький, Передмова (друкується за виданням $з$ 1935), [в:] В. Ткачук, Золоті дзвінки, підготовка текстів, упоряд. та післяслово Р. Горака, Львів 2014, с. 5-6; І. Огієнко, Василь Ткачук: „Зимова мелодія”, „Рідна мова” 1939, ч. 3, с. 139-140; І. Вільде, Василь Ткачук: „Золоті дзвінки”, [в:] її ж, Незбагненне серие, упорядкув., вст. стаття Забутий світ Ірини Вільде і прим. М.А. Вельо, Львів 1990, с. 14-18; І. Вільде, Гість у нашій редакиії, [в:] іï ж, Незбагненне серие, упорядкув., вст. стаття Забутий світ Ірини Вільде і прим. М. А. Вельо, Львів 1990, с. 11-13; Т. Мигаль, Ми не забули тебе, легінику, „Літературна Україна”

Slavica Wratislaviensia 168, 2019

(C) for this edition by CNS 
містичнішою у порівнянні з творами його славнозвісного попередника Василя Стефаника ${ }^{2}$, вона наскрізь пройнята мотивами й образами смерті. 3-поміж близько шістдесяти новел, що ввійшли до виданої у 2013 році збірки Сині чічки (2013), у половині з них більшою або меншою мірою присутні мотиви й образи смерті. Таке дослідження цікаве й тим, що передчасно

1965, 8 червня; В. Лучук, Письменник-демократ, [в:] В. Ткачук, Новели, Львів 1973, с. 3-8; Я. Дорошенко, Ім'я відновив ювілей, „Галичина” 1991, 30 січня; В. Морозюк, Золоті дзвінки Василя Ткачука, „Галичина” 2001, 13 вересня, с. 10; С. І. Хороб, Один із когорти учнів славетного новеліста (Прозова творчість В. Ткачука), „Вісник Дніпропетровського університету ім. Альфреда Нобеля. Серія «Філологічні науки»" 2013, № 2, с. 222-228; Х. Федор, Василь Ткачук в західноукраїнському літературному та культурному проиесі початку XX столітmя, „Гуманітарна освіта в технічних вищих навчальних закладах” 2014, № 29, с. 260-278; Х. Федор, Василь Ткачук крізь призму розгортання ним стефаниківських традищій, „Гуманітарна освіта в технічних вищих навчальних закладах” 2015, № 31, с. 231-243; Х. Федор, Колористика творів Василя Ткачука та ї роль у висвітленні ідейно-художніх домінант прози письменника, „Гуманітарна освіта в технічних вищих навчальних закладах” 2014, № 30, с. 235-243; Х. Синітович, Життєвий і творчий шлях Василя Ткачука, [в:] В. Ткачук, Сині чічки. Новели, Івано-Франківськ 2013, с. 5-13; Р. Горак, Загублений талант Василя Ткачука, [в:] В. Ткачук, Золоті дзвінки, підготовка текстів, упоряд. та післяслово Романа Горака, Львів 2014, с. 239-303; Р. Горак, Василь Ткачук з Іллінців, „Перевал” 2015, ч. 3-4, с. 294-304; О. Гоффманн, До сторіччя з дня народження Василя Ткачука - спогади дочки письменника, [в:] „Almanach Ukraiński 2016”, ред. R. Kramara, Warszawa 2016, c. 260-270; О. Гоффманн, Хто такий Василь Ткачук. До сторіччя з дня народження, „Наше Слово" 2016, 17 січня, с. 10.

2 Прослідковуючи типологічні паралелі між Василем Ткачуком і Василем Стефаником, дослідники згідно підкреслювали оптимістичніше звучання творів першого 3 названих новелістів. Уже в 1936 році один з тодішніх рецензентів Ткачука, зазначав, що у них „слідно вплив Стефаника і Черемшини. Але чисто зовнішній, бо цілим настроєм, цілою тонацією душі Ткачук безмежно далекий від тих авторів. У Стефаника - понурий трагізм, не раз тривожний, хвилюючий виклик. У Черемшини навіть 3 його „чічками”, „легіньчиками” і Парасочками - поперед всего одчайдушний протест, зухвалий глум. У Ткачука все полите лагідно-фіялковим сяйвом, тихим і покірним ляментом зломаних істновань”. Див.: Р. О., Золоті дзвінки В. Ткачука, „Вістник” 1936, кн. 12, с. 933. У тому ж самому році Остап Грицай, аналізуючи Ткачукову новелу Травень, писав про „прекрасну і нову рису в духовності гуцула, підхоплену Ткачуком”, що стоїть „у протиставленню” „до понурої невблаганности у Стефаника”. Дослідник заохочував молодого новеліста далі „малювати ясні сторони української душі!”. Див.: О. Грицай, Цікавий дебют, „Свобода” 1936, № 109. Сучасні дослідники спадщини Ткачука підтверджують думки тогочасних критиків, зокрема Роман Горак (див.: Р. Горак, Загублений талант Василя Ткачука, [в:] В. Ткачук, Золоті дзвінки, підготовка текстів, упорядкування та післяслово Р. Горака, Львів 2014, с. 268), Степан Хороб (Див. С. І. Хороб, Один із когорти учнів славетного новеліста (Прозова творчість В. Ткачука), „Вісник Дніпропетровського університету ім. Альфреда Нобеля”, серия „Філологічні науки” 2013, № 2, с. 225) чи Христина Федор. Остання справедливо зазначала: „Ткачук описує трагічні ситуації, як і Стефаник, але його герої завжди вірять у краще майбутнє і не доходять до крайнощів” і далі: „Ткачук постає, як світлий пророк майбутнього, вірить у добро, живе з надією на краще, його новели більш оптимістичні та життєрадісні". див.: Х. Федор, Василь Ткачук крізь призму розгортання ним стефаниківських традииій, „Гуманітарна освіта в технічних вищих навчальних закладах" 2015, № 31, с. 236, 241.

Slavica Wratislaviensia 168, 2019

(C) for this edition by CNS 
загиблий (на 28 році життя) письменник - самородний талант, непізнані грані якого ще чекають на своє наукове поцінування ${ }^{3}$.

У текстах Ткачука зображено кілька типів смертей, зокрема раптову смерть у результаті стихійного лиха або нещасного випадку, насильницьку смерть унаслідок убивства чи природний відхід із життя. Так, письменник двічі в своїй творчості побудував сюжет, звертаючись до мотиву стихійного лиха. У новелі Повінь жителі села тонуть у хвилях розбурханої ріки. Заголовна повінь, що „не пардонує”, ставить героїв у межову ситуацію, поглинає людські життя. Особлива увага письменника сфокусована на „кадруванні” моменту смерті „білої киці”, що зараз пливе „в парі” зі „спокійною дівчинкою". Смерть дитини стає символом страшного спустошення, що його спричинила повінь. У Бурі шалений гірський буревій стає свідком крайніх людських пристрастей - викриття зради у коханні, що для зрадженого гірше смерті. I хоча читач не $є$ свідком раптової смерті головного героя, чітко їі усвідомлює і передбачає, на що вказують заключні акорди новели: „Та Іванчіка обняла сердита буря й не пустила, аби не вертався”" Про раптову смерть чоловіка унаслідок нещасного випадку на заробітках дізнається з листа від „краян” героїня новели Нещасні: „Вашого чоловіка Івана Скрипчука пас у фабриці схопив і розшматував" гине і Йосип з новели Перекиньчик. Мужики, які вирішили „відступнику” „кости прочухати” („Най знає: Або з нами, або з панами!...”б), жорстоко вбили його під прикриттям ночі. Сцена наглої смерті героя вражає. Це не деталізований опис акту умирання. Це, характерні для Ткачука лаконічні, уривчасті фрази, в яких важливу роль відіграють звуконаслідувальні слова, що реалістично відтворюють звуки скрадання убійників („Тут... туп... туп... туп... Принишкли. Тут... туп... - Пс-ст!”), ударів дручків („Геп! геп! жбах! жбах!”), стогонів катованого („,- Ой! Гв!... - Йой!...”), урешті, вказують на момент смерті останнього (,Жбах! — i тихо”)

${ }^{3}$ Окрім указаних вище давніх і сучасних нечисленних дослідників творчої спадщини Ткачука і ми присвятили цикл статей грунтовному аналізу окремих аспектів життя і творчості новеліста, зокрема, А. Horniatko-Szumiłowicz, ,, Skromne obrazki wiejskie” Wasyla Tkaczuka (szkic do portretu pisarza zapomnianego), „Studia et Documenta Slavica” 2017, № 1, c. 9-21; А. Горнятко-Шумилович, Майстерність змалювання жіночих постатей у новелістиці Василя Ткачука, [w:] Kobieta w zwierciadle języka i kultury, red. A. Archangielska, M. Hordy, Szczecin 2017, с. 499-517; А. Горнятко-Шумилович, Валиль Ткачук. Між традицією і новаторством (нарис проблематики), [w:] Tożsamość ukraińska wobec przemian XVII-XXI w., red. K. Jakubowska-Krawczyk, A. Nowacki, Lublin 2017, c. 147-163; А. Горнятко-Шумилович, Буря Василя Ткачука (Про забуту новелу „Загубленого таланту”), „Studia Ukrainica Posnaniensia" 6, 2018, c. 197-205.

${ }^{4}$ В. Ткачук, Буря, [в:] його ж, Сині чічки. Новели, передм. Х. Синітович, ІваноФранківськ 2013, с. 164.

${ }^{5}$ В. Ткачук, Нещасні, [в:] його ж, Сині чічки...,, с. 76.

${ }^{6}$ В. Ткачук, Перекиньчик, [в:] його ж, Сині чічки..., с. 46.

7 Там само, с. 47. 
ються („Облизували вуста, ковтали кров зі слиною, прожерали й били”), тварини з переляку навісніють („Пси бігали на лінвах; гавкали, розщибалися. [...] Маржинка рула") ${ }^{8}$. Жахливість убивства підсилена барвами чорною і червоною. Мікрополе чорного кольору репрезентоване у тексті іменником „ніч”, а також прикметниками „чорний” і „темний”, тоді як червоного — іменником „кров”, пор.: „Чорна купка пустилась у діл. Темна хмарка їх доганяла. Чорна меншала-маліла: крапка й никла, як під землю. Так никли в темряві хати, сади”,; „Кров гаряча сикнула на лиця”" ${ }^{\text {; }, ~ А ~ к р о в и, ~ я к ~ с т а в ~}$ розлитий. А крови - озеро"11. Ніч, як очевидиця насильницької смерті, персоніфікована, пор. „Ніч йойкнула й затихла”; „Ніч стогнала”12; „Ніч свідок"13.

Мотив насильницької смерті наявний і в новелі За штрикою, чи не найсильнішій 3-поміж зразків „малої прози” Ткачука. Незважаючи на факт, що подієвим стрижнем твору є розпач матері після втрати сина, а сам акт умирання не $\epsilon$ предметом опису, окремі деталі дозволяють читачу уявити собі моторошність сцени вбивства. Коли стара Михайлиха не застала сина-втікача у криївці в житах, а замість цього „самітне леговище”, „розтолочені колоски - й сліди підків - залізних — острих", зрозуміла, що їі одинака вбито. Про жорстокість убивства свідчить розлита кров, якої земля вже не приймає: „,...] спивала [Михайлиха - А. Г.-Ш.] кровцю сина свого. Спивала, бо земля не могла всю випити [...]"14. Смерть молодого хлопця доводить до божевілля не лише матір („Впали миски з рук. [...] Впала й вона на леговище й пищала не своїми голосами" ${ }^{15}$ ). Ціле довкілля вторує Михайлисі:
Стогне лан...
Йойкає перелісок...
Квилять дроти...
Дрижать рейки...
Пташня утікає в корчі ${ }^{16}$.

I врешті, насильницькою смертю вмирають герої новели Тіни, які застрелили один одного: „[...] дві кулі розминались зі собою: одна повалила чорну тінь за ліщиною, одна звалила Юрія з ніг"17.

Симптоматично, що Ткачукові герої нечасто помирають природною смертю, як напр. Гричкун з новелі Мяснииі, Дмитро з новелі Свічка потахла

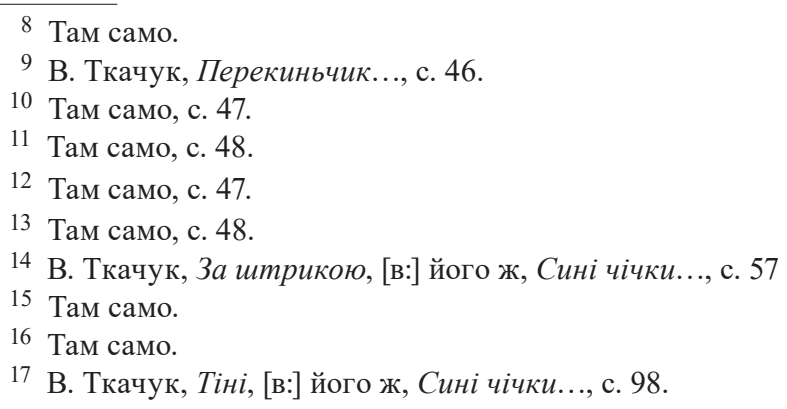


чи Федір з Останніх гонів. До цього ж тільки двох 3 названих вище героїв помирає на схилі віку. В останньому випадку герой прощається з життям унаслідок ускладнень після воєнних ран. I хоча помирає у власному домі, його смерть передчасна, немає на неї згоди ні вмираючого, що тужить за землею, ні його рідні: „Замикав очі й сухі вуста тулив до розпареної землиці. А жінці сльози випікали очі [...]"18.

Прикметно те, що смерть наздоганяє Ткачукових героїв у різному віці: дитячому, молодечому, зрілому, старечому. Відтак, образ смерті різний в залежності від віку умирання. Так, у дитячому віці помирає „дівчинка”, яку захопила повінь з однойменної новели. Образ мертвої дитини не відштовхує. Вона „спокійна”, у неї „срібно-жовте волоссячко”. Увага автора сфокусована на невідворотно втрачену юність, зрештою і ціле життя дитини, в якої іще вчора сонце і вітерець „підкидали кучеряками, що подобали на сухоквітки. Любувались ними, як сестрички спідничками, або братчики капелюшками"19. Для підсилення драматизму ситуації, автор зіставляє смерть дівчинки зі смертю маленької киці, що так само ,[...] весела, безжурна, як мамина доня”: ,„У парі - біла киця й спокійна дівчинка карбулялись, як хвилі хотіли, як аж повінь багла" 20 .

По-іншому відтворена сцена смерті людини в силі віку, але вимученої болем і терпінням. Так, напр. в новелі Останні гони помирає Федір, вражений ворожою кулею. Процес умирання героя сповнений болю і страждання: „Федір, як стара хата: трісне кожел, вичовгається стріха, вигнуться сволоки - так його кости розкладаються окремо, так болять, що ліпше смерть, як така мука..."21. Дружина не може змиритися 3 передчасною смертю чоловіка. Голосить $^{22}$ („,Господарику мій, господарику! Де ж ти си вібираєш, на кого мене покидаєш?..."23), а коли чоловік помирає, намагається повернути його до життя (,Жінка 3 розпукою бралась зводити Федора; на ноги класти [...]”24).

I, врешті, смерть старої людини невідворотно пов'язана з фізичним розпадом. У старого Гричкуна з новели Мясниці „чорні вуста, мов вуголь, а там, де очі, і дві чорні плями, в них втоплені були білі гудзики. Скіра жов-

18 В. Ткачук, Останні гони, [в:] його ж, Сині чічки...,, с. 105.

19 В. Ткачук, Повінь, [в:] його ж, Сині чічки..., с. 59.

20 Там само, с. $58,59$.

21 В. Ткачук, Останні гони..., с. 105.

22 Голосіння (плачі, оплакування, йойкання, побивання, желенія, причитування тощо) - ритуальне дійство над покійником, своєрідна обрядова розмова з померлим. Голосили, як правило, жінки, в хаті або над могилою. Під час голосіння зверталися до небіжчика, виражаючи жаль з приводу його смерті, закликали повернутися, піднятися, докоряли йому, що покинув рідних і своє господарство. Джерела цього ритуалу сягають часів язичництва. Див. напр.: В. Войтович, Українська міфологія, Київ 2002, с. 109.

23 Там само.

24 Там само, с. 106. 
та, як віск. [...] ...Зуби, як при коліні завели аркана по хаті, а змучені падали в калюжу крови, що стояла серед хати, як тихе озеро"25.

Ткачукові герої балансують на межі життя і смерті, передчуваючи і по-

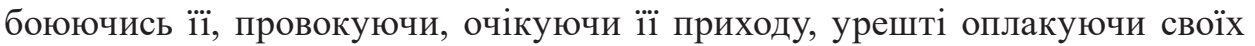
померлих близьких.

Чимало $з$ постатей, змальованих письменником, передчувають власну кончину або смерть своїх близьких. Так, Параска з новели Тато й одинак голосить, немов над умерлими, ще за живими чоловіком і сином, які готуються на війну. Згорьована героїня озвучує лихі передчуття гіркими докорами: „- Не пустю! Аби, отут — амінь був! Аби мали копитами розмісити! На кого мене лишаєте, з ким між люде піду?...Сидіть дома, най ваші голови спокійні будуть, та най на ваше тіло рани не чигають" 26 . Передчуває свою смерть і загиблий на війні Васильків батько з новели Василько. Прощаючись 3 жінкою, і дитиною, зронив сльозу, висказав маленькому синові заповітні слова. Семен-Пілій з новели Вiддай ниву передчуває скору смерть і просить Бога відстрочити її, щоб міг звільнитися від тяжкого гріха палійства: „— Господи, Йсусе! Тримай ту скажену смерть, най я завтра діжду, щоб висповідатися міг"27. Андрусь і Павлусь 3 новели Яблуко виконують прохання вмираючої матері роздобути яблуко. Незважаючи на непереможне прагнення скоштувати його, не наважуються зробити це, підсвідомо розуміючи, що бути може це останнє бажання хворої матері. Молодший з хлопців „підніс яблуко та гострими зубками пробив його”, але не посмів з'їсти хоч кусок: „- Ненька терплять голодні, а я?! - подумав" 28 . Усвідомлення дитиною скорої смерті матері викликає невисловлену тугу й потребу материнської ласки: „Забагав, щоб неня й тепер погладила його ріпавою рукою тай заспівала" 29.

У творах Ткачука герої відчувають реальний страх перед смертю своїх рідних. Це призводить їх до радикальних дій, іншим разом викликає напади божевілля. Так, напр. хвора на туберкульоз мати з новели Близнюки, прогнозуючи скору власну смерть і побоюючись смерті заголовних близнюків, покидає їх у лісі. Поради, які дає їм, безпосередньо вказують на страх героїні перед імовірним ураженням дітей хворобою і в результаті перед їхньою смертю: „Розказуйте все по правді, що неня ваша несумлінна, не хотіла, аби ви конали в сухотах, як вона [...]"30. Видіння кончини власних дітей мучить батька 3 новели Злодій („Урвався терпець. Розщінкав худі, оброслі груди: - Нате! Їжте мене, їжте мої груди - серце жбовхало, обличчя біліло, як сніг ставало..." ${ }^{\prime 31}$. Герой наважується на крадіж заради врятування їх від голодної

\footnotetext{
25 В. Ткачук, Тато й одинак, [в:] його ж, Сині чічки..., с. 45.

26 В. Ткачук, Мясниці, [в:] його ж, Сині чічки..., с. 29.

27 В. Ткачук, Віддай ниву, [в:] його ж, Сині чічки..., с. 169.

28 В. Ткачук, Яблуко, [в:] його ж, Сині чічки..., с. 161.

29 Там само.

30 В. Ткачук, Близнюки, [в:] його ж, Сині чічки..., с. 144.

${ }^{31}$ В. Ткачук, Злодій, [в:] його ж, Сині чічки..., с. 26.
} 
смерті. Мотив крадіжки наявний і в новелі Пструги, в якій аналогічна ситуація. Батько, дивлячись на голодних дітей, що „як «помурзані», наче песинятка на морозі скавуліли — й по личку пускали слізки"з2, вирішує без дозволу ловити заголовних пстругів.

Прикметно, що у творах Ткачука наявний і мотив балансування Ткачукових героїв (головним чином жіночих персонажів) на межі божевілля з приводу кончини близької людини або їі реальної загрози. Так, напр. Неня-Лесиха 3 однойменної новели збожеволіла після того, як „ті, що в них серця з каменя, а в руках рушниця" 33 забрали їі сина у в’язницю. Тако само і в новелі $\mathrm{He-}$ вістка лагідна й сумирна заголовна невістка після незаконного ув'язнення і1і чоловіка ,[...] пакости в суді наробила. За то, що до Стефана не пустили”; „подрапала, як кіт”, „всьо втікало, як від варіятки [...]”34. В обох випадках героїні невпевнені, чи побачать живими своїх рідних, побоюючись їхньої смерті, опиняються на межі божевілля.

Буває, що Ткачукові герої провокують смерть, балансуючи на тонкій грані життя і смерті. Так, напр. молодий Іван 3 новели Прибаг, не захотівши рекрутуватись, випиває зілля-отруту („щось прибаг, аби лишитися, аби не служити!...”35). Його страждань („Стогнав, наче пробитий віл”36) не може здержати мати, яка шукає порятунку в циганки, але й, традиційно для Ткачука, природа, що вторує людині (,Здається, небо так само стогнало, бо не могло вдержати турми хмар"37). У певному сенсі провокує неминучу смерть Іванчік з новели Буря. Вибігаючи у розпал буряної стихії після того, як дізнався про зраду жінки, прирікає себе на певну смерть, на що посередньо вказує одна з віртуозних метафор, характерних для поетики новел Ткачука: „Блискавиці гадюками вилися кругом нього. А він кинув їм своє серце, аби посікли, бо й так трісло на дві половини"38. Провокує власну загибель старий Юрко з новели Юркова весна. Покинутий напризволяще сільським багачем після років наймитування, ,у хаті без вікон, забитих дошками, лежав худий, блідий, як від смерті вернувся..."39. У героя поступово наростає озлобленість, що у результаті призводить його до бажання смертельної помсти на кривднику. I хоча читач не є свідком смерті ні безжального багача, ні Юрка, завдяки думкам і діям героя, усвідомлює невідворотність смерті обох: „- Гей, дідичку дорогенький! Підемо обидва високо, до неба, до Бога підемо. [...] Я тебе на цім світі не лишу, не лишу”40. I, врешті, „ненависть,

\footnotetext{
32 В. Ткачук, Пструги, [в:] його ж, Сині чічки..., с. 87.

33 В. Ткачук, Неня-Лесиха, [в:] його ж, Сині чічки..., с. 146.

34 В. Ткачук, Невістка, [в:] його ж, Сині чічки..., с. 25.

35 В. Ткачук, Прибаг, [в:] його ж, Сині чічки..., с. 96.

36 Там само, с. 95.

37 Там само.

38 В. Ткачук, Буря..., с. 164.

39 В. Ткачук, Юркова весна, [в:] його ж, Сині чічки..., с. 137.

40 Там само, с. 138.
} 
завзятість і кривда-біль” керують вчинками й іншого Ткачукового героя - Семена $з$ новели Вiддай ниву. Ошуканий Онуфрієм, який забрав йому й жінку, й землю (,Запроторив ти мою жінку московським козакам, а ниву - землицю загарбав"41), герой наважується підпалити Онуфрієву хату, провокуючи власну раптову смерть („Та кров бухнула й затопила решту його слів. Та кров, та той міхур болю, що під серцем цієї ночі вчинився. Тепер тріс. Лежав тихо й лагідно,42).

Нерідко герої новел Ткачука усвідомлюють незабарну смерть, очікуючи іï приходу з нетерпінням, але частіше з переляком і сумом. Так Стефан 3 новели Флояра грає, який три роки оплакує померлу жінку, розуміє, що скоро помре і жде приходу смерті як свого роду спасіння від нестерпної туги за небіжкою: „...Аді, рветься моя нитка - (а була гудзувата!) кінчу вже - таки причувається, що смерть дуднить" ${ }^{23} .3$ нетерпінням очікує смерті старий Гричкун з новели Мясниці. Судячи, що не може вмерти з приводу гріха життя на віру, просить жінку покликати священика, щоб той дав їм шлюб: „, Я старої дати чоловік, хочу скінчити, як мої дєді... Йди небого, до ксьондза, най слюб нам дасть [...]”44. Гричкунової смерті як звільнення від житейських турбот і тілесних мук очікує жінка, яка голосить: „- Боже, що за мука... Ні жити, ні вмерти... За що така кара... Ні вмолити, ні впросити..." ${ }^{4}$, але й солідарна 3 односельчанином сільська громада, що лейтмотивно відзначено у творі. Пор. „Гричкун буде вмирати. Село банує”, „Село переповідало: - Гричкун не може вмерти! Мучиться сарака..." разнення зв'язку вмираючого з сільською громадою новеліст використав прийом прозаїчної анафори, що зв'язує початки суміжних речень:

Село говорило-розбалакувалося.

Село — 3 дива не сходило — чудувалось.

Село метушилось... ${ }^{47}$

Коли старий помер, село зітхнуло полегшено, про що сповіщали церковні дзвони. I знов анафоричний повтор:

Дзвони гикали-розбалакувалися [...]

Дзвони стукали в шибки; [...]

Дзвони грали-вигравали...

...А дзвони били-вигравали ${ }^{48}$.

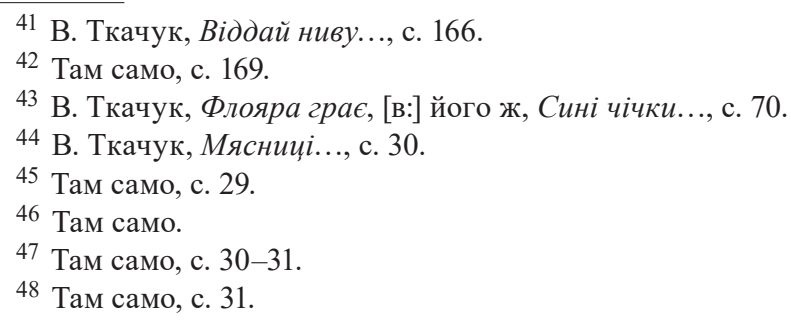


Ткачукові герої не тільки самі очікують смерті, передбачають і провокують її, але й оплакують своїх померлих родичів. Так, напр. дія новели Зелені свята розгортається на сільському цвинтарі. Матіїха-мати наймає парастас за душі загиблих незнайомих воїнів. Не знає, де загинув їі син і вгамовує свою тугу за померлим: „— Якби-м своєму синови наймала парастас, так їм наймаю, най Бог прийме за душі померші. [...] То й не жалую їм парастас наймити, здається мені, що всі мої сини, а я їх мати..."49 Оплакує сина і всіх хлопців, що загинули на війні, не лише стара Матіїха, але й цвинтарні дерева: „старі липи, що в своїх тінях цвинтар ховають і над могилами-гробами шепочуть, моляться за грішні душі" ${ }^{50}$. У новелі Флояра грає чоловік „банує” за померлою жінкою: „Так Стефан за небіжкою банував” Його розпач відлунюється у довкіллі: „Від його слів, здавалося, грунь вгинався, каміння скочувалося, скали розтріскувалися" 52 . Так само і в новелі Мосяжні серия Олекса, який після смерті дружини „чорним костуром вигримував по хаті”, „замовкав, як той ясень [...], та інколи лютився, як буря [...]" "53. Іваниха з новели Нещасні оплакує загиблого на заробітках у Франції чоловіка. Не хотівши „додавати жалю” маленьким дітям, які чекали листа від батька, не сказала про його смерть, а „взяла з-під образів Іванову світлину й дала, щоб дивилися" 54 . Жаль за померлим виражений не у в вигляді традиційного ритуалу голосіння. Висловлення туги й горя, болю й розпуки здійснене за допомогою засобу возвеличування й ідеалізування покійного на світлині, що у цьому випадку склав своєрідний поетичний арсенал дружини-плакальниці: „...Іван рівно стояв, простенько. Буйний волос гарно був причесаний, а обличчя, як білий колач. Сорочка з нагрудником прикривала широкі груди"

У новелах Ткачука незміренні провалля материнського розпачу. Так, напр. у новелі За шттикою для крайнього увиразнення туги матері за померлим сином Ткачук застосовує і відомий з пісенного фольклору прийом т. зв. заперечного паралелізму: „То не буря, запутавшись у густі смереки, виє-вийойкує, то за штрикою Михайлиха стогне, плаче" 56 , і риторичне звертання, коли ошаліла від розпачу Михайлиха звертається до сина, якого вбили, і до сонця, що за гори закотилось: „—-Сину, де ти !? Сонце, де ти?!?..."

Поміж прозових перлин галицького новеліста є твори, в яких смерть не є стрижнем розповіді, а проступає ніби в іiі тлі. Так, напр. заголовний

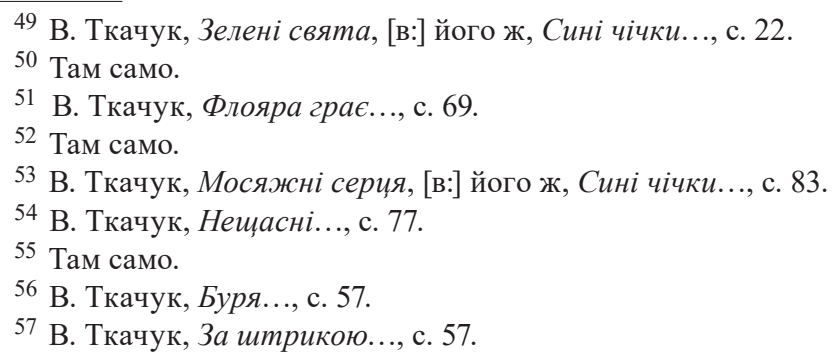


Василько з однойменної новели росте на потіху матері. Він напівсирота, оскільки батько загинув на війні. Сповитим туманом спогадам хлопчика про батька присвячений другий з семи відступів-мінірозділів новели. У короткому фрагменті промовисті натяки на батькову тугу прощання з сім'єю (,-- Поцілував неню довго й зі сльозами. Його теж у чоло, в голівку” $\left.{ }^{\prime 5}\right)$, батьківську турботу за маленького сина, його виховання (,- Рости синку. Слухай неньку, будь розумний, а як підростеш, думай аби не лиш тобі добре було, але всім таким, як ти"59), любов дитини до рідного батька (,- - Ненько - ненько! Не пустіть дєдика, не пустіть!”60).

Цікаво, що, попри доволі часте використання Ткачуком мотивів й образів смерті, само слово „смерть” (чи його синоніми) ужите письменником небагато разів, утім в новелі Віддай ниву. Тут смерть героя-палія персоніфікована, зображена у поєднанні з полум'ям вогню: „Смерть і вогонь. Обережно розмовляли..."61. В Останніх гонах оповідач співчуває Федору, якого кості „так болять, що ліпше смерть, як така мука"62. Прикметно те, що вказане вище слово не виступає у жодному з заголовків біля шістдесяти новел. Тільки у двох назвах наявні посередні натяки на сюжет, пов'язаний зі смертю: Свічка потахла й Останні гони. У першій з них палаюча свічка - це символ життя, яке кінчиться, коли вона тахне і гасне (,...А на столі свічка догоряла. Іще раз кліпнула, замигала, а потім потахла..." $\left.{ }^{63}\right)$. У другій — гони - це народна міра довжини; словосполучення „останні гони” означає тут останню дистанцію (останні кроки, хвилини) на життєвому шляху героя. Окрім вищесказаного, концепт „смерть” екстеріоризується у новелах Ткачука за допомогою іменників: „могила” („Ворожа куля прошила смілу грудь і свіже тіло спакували в тісну могилу”"64), „гріб” („старі липи [...] над могилами-гробами шепочуть, моляться за грішні душі” $\left.{ }^{2}\right)$, „цвинтар”, „парастас" („А коли ивинтар убрався у багато парастасів, тоді священик ішов...”66), „хрест” („Прийшла: три рази цмокнула хрест”67), „небіжка” („Небіжку підвіяло, скрутило”68), а також дієслів: „вмирати”/,вмерти”

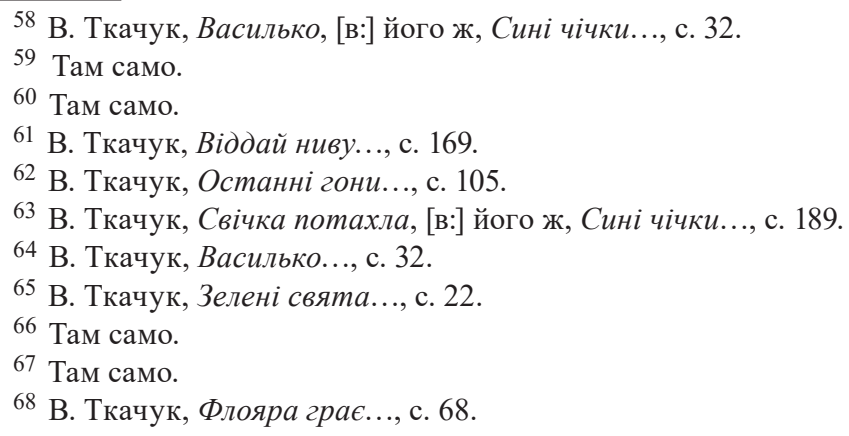


(„Гричкун буде вмирати”; „Ні жити, ні вмерти”69; „Він умер...”70), „сконати" (,там сконати хочу"71).

Ткачукові герої, як правило, не хочуть прощатись із життям. В останні хвилини земного існування охоплює їх туга і жаль за тим, що лишають. Так, напр. старий Дмитро з новелі Свічка потахла помирає у Свят-вечір. Перед смертю приймає колядників, яким кволим голосом помагає колядувати. Скорий відхід із життя викликає у вмираючого сум і сльози: „Дмитро ймився за груди, аби серце йому не вилетіло 3 них, як птаха 3 клітки. Та й очі замикав, аби сльози затамувати, щоб не розсипалися всі...”72

Свого часу одна 3 нечисленних сучасних дослідниць творчої спадщини Ткачука Христина Федор, порівнюючи його твори з новелами Василя Стефаника, справедливо констатувала: „Якщо для Стефаникових персонажів смерть - бажаний порятунок від злиднів, то Ткачук шукає для своїх героїв завжди іншого виходу із ситуації, менш драматичного"73. I справді, чимало його новел, зокрема Грішник, Родимий, Черешні, Бог гнівавбиси, Набуток, Літо, Старосвітська, Весна та ін. за своєю тональністю - життєствердні.

I навіть за умови, що, за словами дослідниці, Ткачук „постає як світлий пророк майбутнього, вірить у добро, живе з надією у краще"74, мотиви й образи смерті широко репрезентовані в його новелах, що зумовлене у першу чергу складним становищем, у якому опинились західноукраїнські землі у 20-х і 30-х роках XX ст., лейтмотивною для письменника темою села, мужицьких злиднів, урешті, важким особистим досвідом. Сам письменник мав написати в своїй автобіографії: „,...] серед невигод, у голоді, зростав я і виховувався"75. А його товариш по перу з львівського угрупування „Дванадцятка”- Анатоль Курдидик (під крипт. А.) зауважував: „Василь привіз зі собою до Львова шматок запрацьованої, окервавленої і втомленої з турбот і злиднів Гуцульщини"76. А, отже, смерть для Ткачукових героїв - не вихід із скрути, а невідворотний, закономірний і завершальний етап на їхньому непростому життєвому шляху. Сам Василь Ткачук, як пристрасний любитель життя, не поетизує смерті, але це важливий мотив його новел і тому-то, володіючи багатою палітрою художніх засобів, створює неповторні їі образи у різних їх іпостасях.

69 В. Ткачук, Мясниці..., с. 29.

70 В. Ткачук, Нешасні..., с. 76.

71 В. Ткачук, Останні гони..., с. 105.

72 В. Ткачук, Свічка потахла, с. 188.

73 Див.: Х. Федор, Василь Ткачук..., с. 236.

74 Там само, с. 241.

75 Цит. за: Р. Горак, Василь Ткачук з Іллінців..., с. 303.

76 Цит. за: В. Габор, „Дванадиятка”. Наймолодша львівська літературна богема 30-х років ХХ століття: Антологія урбаністичної прози, Львів 2006, с. 294. 


\section{Бібліографія}

Doroshenko Ja., Im'ja vidnovyv juvilej, „Galychyna” 30 sichnja 1991.

Fedor H., Kolorystyka tvoriv Vasylja Tkachuka ta i'i' rol' u vysvitlenni idejno-hudozhnih dominant prozy pys'mennyka, „Gumanitarna osvita v tehnichnyh vyshhyh navchal'nyh zakladah” 30, 2014.

Fedor H., Vasyl' Tkachuk kriz' pryzmu rozgortannja nym stefanykivs'kyh tradycij, „Gumanitarna osvita v tehnichnyh vyshhyh navchal'nyh zakladah" 31, 2015.

Fedor H., Vasyl' Tkachuk v zahidnoukrai'ns'komu literaturnomu ta kul'turnomu procesi pochatku XX sto-littja, „Gumanitarna osvita v tehnichnyh vyshhyh navchal'nyh zakladah” 29, 2014.

Gabor V., „Dvanadcjatka”. Najmolodsha l'vivs'ka literaturna bogema 30-h rokiv XX stolittja: Antologija urbanistychnoi' prozy, L'viv 2006.

Goffmann O., Do storichchja z dnja narodzhennja Vasylja Tkachuka — spogady dochky pys'mennyka, [v:] ,,Almanach Ukraiński 2016”, red. R. Kramara, Warszawa 2016.

Goffmann O., Hto takyj Vasyl' Tkachuk. Do sto-richchja z dnja narodzhennja, „Nashe Slovo” 17 sichnja 2016.

Golubec' M., Debjut novelista, „Novyj chas” 10 lystopada 1935.

Gorak R., Vasyl' Tkachuk z Illinciv, „Pereval” 2015, № 3-4.

Gorak R., Zagublenyj talant Vasylja Tkachuka, [v:] V. Tkachuk, Zoloti dzvinky, pidgotovka tekstiv, uporjad. ta pisljaslovo R. Goraka, L'viv 2014.

Grycaj O., Cikavyj debjut, „Svoboda” 1936, № 109.

Horniatko-Szumiłowicz A. ,Skromne obrazki wiejskie” Wasyla Tkaczuka (szkic do portretu pisarza zapomnianego), „Studia et Documenta Slavica” 2017, № 1.

Horniatko-Szumiłowicz A., Майстерність змалювання жіночих постатей у новелістиці Василя Ткачука, [w:] Kobieta w zwierciadle języka i kultury, red. A. Archangielska, M. Hordy, Szczecin 2017.

Horniatko-Szumiłowicz A., Валиль Ткачук. Між традицією і новаторством (нарис проблематики), [w:] Tożsamość ukraińska wobec przemian XVII-XXI w., red. K. JakubowskaKrawczyk, A. Nowacki, Lublin 2017.

Horniatko-Szumiłowicz A., Буря Василя Ткачука (Про забуту новелу „Загубленого талан$m y ”)$, „Studia Ukrainica Posnaniensia” 6, 2018.

Horob S. I., Odyn iz kogorty uchniv slavetnogo novelista (Prozova tvorchist' V. Tkachuka), „Visnyk Dnipropetrovs'kogo universytetu im. Al'freda Nobelja. Serija „Filologichni nauky” 2013, № 2.

Luchuk V., Pys'mennyk-demokrat, [v:] V. Tkachuk, Novely, L'viv 1973.

Morozjuk V., Zoloti dzvinky Vasylja Tkachuka, „Galychyna” 13 veresnja 2001.

Mygal' T., My ne zabuly tebe, leginyku, „Literaturna Ukrai'na” 8 chervnja 1965.

Nygryc'kyj L., Peredmova (drukujet'sja za vydannjam z 1935), [v:] V. Tkachuk, Zoloti dzvinky, pidgotovka tekstiv, uporjad. ta pisljaslovo R. Goraka, L'viv 2014.

Ogijenko I., Vasyl' Tkachuk: ,Zymova melodija”, „Ridna mova” 1939, № 3.

R. O., Zoloti dzvinky V. Tkachuka, „Vistnyk” 1936, kn. 12.

Rudnyc'kyj M., Sil's'kyj hlopchyna dyvyt'sja na svit, „Dilo” 19 lystopada 1935.

Rudnyc'kyj M., Vasyl' Tkachuk ,Vesna”, „Literatura i mystectvo” 1940, № 1.

Semchyshyn M., Selo v narysah Vasylja Tkachuka, „Nash prapor” 17 zhovtnja 1935.

Synitovych H., Zhyttjevyj i tvorchyj shljah Vasylja Tkachuka, [v:] V. Tkachuk, Syni chichky. Novely, Ivano-Frankivs'k 2013.

Tkachuk V., Syni chichky. Novely, peredm, H. Synitovych, Ivano-Frankivs'k 2013.

Vil'de I., Gist' u nashij redakcii', [v:] yii zh, Nezbagnenne serce, uporjadkuv., vst. stattja Zabutyj svit Iryny Vil' de i prym. M. A. Vel'o, L'viv 1990.

Vil'de I., Vasyl' Tkachuk: „Zoloti dzvinky”, [v:] yii zh, Nezbagnenne serce, uporjadkuv., vst. stattja Zabutyj svit Iryny Vil' de i prym. M. A. Vel'o, L'viv 1990.

Vojtovych V., Ukrai'ns'ka mifologija, Kyi'v 2002. 


\section{On the scales of fate. Motifs and imagery of death in Vasil Tkachuk's novellas}

Summary

Although Vasil Tkachuk's (1916-1944) novellas are considered to be somewhat optimistic in comparison to the works of his great predecessor Vasil Stefanyk, they are also abundant with imagery and motifs of death. In Tkachuk's writings, death is ever-present in its various forms, be it a natural death, a sudden death caused by natural disaster, or murder. Death afflicts everyone. It strikes down the innocent and young, the mature and elderly. Tkachuk's characters balance on edge between life and death, sensing that death is approaching, fearing it, provoking, waiting for it to come, and finally, grieving their beloved ones. Tkachuk's literary preoccupation with death seems to be even more interesting because he died prematurely, at the age of 28 . He was a selfmade talent, an essential voice in the Ukrainian literature of the 1930 s, a writer whose works duly deserve more attention from literary scholars.

Keywords: imagery of death, motifs of death, novellas, Ukrainian literature

\section{Na szalach losu. Motywy i obrazy śmierci w nowelistyce Wasyla Tkaczuka}

\section{Streszczenie}

Chociaż nowele Wasyla Tkaczuka (1916-1944) w porównaniu z utworami jego wielkiego poprzednika - Wasyla Stefanyka - postrzegane są jako bardziej optymistyczne, również one w znacznej mierze przesycone są motywami i obrazami śmierci. W tekstach Tkaczuka śmierć jest nieustannie obecna, w jej rozmaitych odmianach — pojawia się śmierć naturalna, nagła śmierć z powodu klęski żywiołowej, gwałtowna śmierć na skutek zabójstwa itp. Śmierć dopada bohaterów w różnym wieku: dziecięcym, młodzieńczym, dorosłym, podeszłym. Bohaterowie utworów Tkaczuka balansują na granicy życia i śmierci, przeczuwając jej nadejście, obawiając się jej, prowokując ją, oczekując jej wizyty, wreszcie — opłakując bliskich im zmarłych. Zgłębienie tematu śmierci w tekstach Tkaczuka jest tym bardziej interesujące, iż ów przedwcześnie zmarły (w wieku 28 lat) pisarz to samorodny, nowo odkryty talent ukraińskiej literatury lat trzydziestych XX wieku, który w pełni zasługuje na należytą uwagę badaczy.

Słowa kluczowe: motywy i obrazy śmierci, nowelistyka, literatura ukraińska 